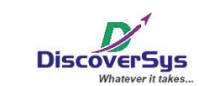

Published by DiscoverSys

\section{Determinant factors of infant mortality in Bima District in 2012}

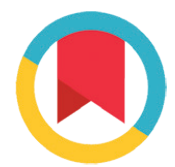

CrossMark

$$
\text { Rini Hendari, }{ }^{1,4^{*}} \text { I Ketut Tangking Widarsa, }{ }^{1,3} \text { Dewa Nyoman Wirawan }{ }^{1,2}
$$

\section{ABSTRACT}

The infant mortality is the death of a child before the age of one year, can be caused by endogenous and exogenous factors. The infant mortality rates influenced by family income, maternal age, birth spacing, the frequency of the ANC visits, the place of delivery, birth weight, breastfeeding, immunisation, maternal knowledge about infant care, clean water sources sanitationary and education related to infant mortality. The purpose of this research was to identify the determinant factors of infant mortality in Bima regency. The type of research is observational analytic, with a case-control study design. The cases were infant who died in January to December 2012, while the control were infant who still alive on the same period. Cases and controls were selected from the community of Bima District. They were selected by using stratified proportional sampling technique and in total they were 153 respondents with a ratio of 1 to 2. Data was collected through interviews and midwives registers documentation. Data were analysed using chi square test and logistic regression. The result showed that the birth weight $<2500 \mathrm{gr} 0 \mathrm{R}=6.69$ (95\%Cl: $2.11-21.16)$, birth spacing $<24$ months $0 \mathrm{R}=6.69$ (95\%Cl: $2.11-$ 21.16), maternal age $<20$ or $>35$ years $O R=6.63$ ( $95 \% \mathrm{Cl}: 1.84-23.90)$, not exclusively breastfeeding $0 \mathrm{R}=6.23(95 \% \mathrm{Cl}: 2.10-18.46)$, education related to infant mortality $\mathrm{OR}=6.02(95 \% \mathrm{Cl}: 2.17-16.65)$ and clean water sources sanitationary $\mathrm{OR}=3.72(95 \% \mathrm{Cl}: 1.35-10.25)$. It can be concluded that birth weight $<2500 \mathrm{gr}$, spacing births $<24$ months, maternal age $<20$ or $>35$ years, not exclusively breastfeeding, education related to infant mortality, clean water sources sanitationary were determinants of infant mortality with the overall contribution of $61.1 \%$. Improving education and promotion related to nutritional requirement for pregnant women, delay in age of marriage, pregnancy planning and exclusive breastfeeding in Bima District are highly essential.

Keywords: determinants, infant mortality, Bima District

Cite This Article: Hendari, R., Widarsa, I.K.T., Wirawan, D.N. 2013. Determinant factors of infant mortality in Bima District in 2012. Public Health and Preventive Medicine Archive 1(2): 121-127. D01:10.15562/phpma.v1i2.174

\title{
Faktor determinan kematian bayi di Kabupaten Bima tahun 2012
}

\section{ABSTRAK}

Kematian bayi adalah kematian anak sebelum mencapai umur satu tahun, disebabkan oleh faktor endogen dan eksogen. Faktor yang berperan terhadap kematian bayi adalah faktor pendapatan keluarga, umur ibu, jarak kelahiran, frekuensi ANC, tempat persalinan, berat bayi lahir, ASI eksklusif, immunisasi, pengetahuan ibu tentang perawatan bayi, sumber air bersih dan frekuensi penyuluhan kesehatan. Tujuan penelitian ini adalah untuk mengetahui faktor determinan kematian bayi. Jenis penelitian adalah observasional analitik dengan rancangan studi kasus kontrol, dimana kasusnya adalah bayi yang meninggal pada periode Januari-Desember 2012 dan kontrolnya bayi hidup pada periode yang sama. Kasus dan kontrol dipilih di masyarakat Kabupaten Bima dengan cara stratified proporsional sampling dengan perbandingan 1 banding 2. Data dikumpulkan melalui wawancara dengan kuesioner dan data sekunder register bidan desa. Analisis data menggunakan uji chi square dan regresi logistik. Hasil analisis data didapatkan faktor risiko berat bayi lahir $<2500$ gr $0 \mathrm{R}=7,38$ (95\%Cl: 2,04-26,70), jarak kelahiran $<24$ bulan $O R=6,69$ (95\%Cl: 2,11-21,16), umur ibu $<20$ atau $>35$ tahun $0 R=6,63$ (95\%Cl; 1,84-23,90), ASI tidak eksklusif OR=6,23 (95\%Cl: 2,10-18,46), frekuensi penyuluhan jarang $\mathrm{OR}=6,02(95 \% \mathrm{Cl}: 2,17-16,65)$ dan sumber air bersih non perpipaan $\mathrm{OR}=3,72(95 \% \mathrm{Cl}: 1,35-10,25)$. Berdasarkan hasil penelitian dapat disimpulkan bahwa berat bayi lahir $<2500 \mathrm{gr}$, jarak kelahiran $<24$ bulan, umur ibu $<20$ atau $>35$ tahun, ASI yang tidak eksklusif, frekuensi penyuluhan yang jarang dan sumber air bersih non perpipaan terbukti meningkatkan risiko kematian bayi, dengan kontribusi sebesar $61,1 \%$. Meningkatkan pengawasan dan monitoring kepada puskesmas-puskesmas dalam kegiatan penyuluhan tentang pentingnya gizi ibu hamil, penundaan usia perkawinan, penjarangan kehamilan dan pemberian ASI eksklusif di Kabupaten Bima sangat diperlukan.

*Correspondence to: Rini Hendari, Public Health Postgraduate Program Udayana University, Nursing Program of Mataram Health Polytechnic rinihendari@yahoo.co.id 


\section{PENDAHULUAN}

Bayi menjadi fokus dalam setiap program kesehatan karena sedang berada dalam masa pertumbuhan dan perkembangan, serta setiap saat menghadapi ancaman kelangsungan hidup seperti kesakitan dan kematian. ${ }^{1}$ Pembangunan kesehatan di Indonesia jauh tertinggal dibanding negara-negara di wilayah Asia seperti Malaysia, Thailand, Srilangka dan RRC. Perbandingan angka kematian bayi (AKB) Indonesia dengan keempat negara tersebut menunjukan hasil yang kurang baik ${ }^{2}$ yaitu 32 per 1000 kelahiran hidup untuk Indonesia sedangkan Malaysia, Thailand, Srilanka dan RRC secara berurutan adalah 15,87; 17,63; 18,57 dan 20,25. Apabila dibandingkan, maka AKB Indonesia besarnya hampir dua kali lipat ratarata $\mathrm{AKB}$ di empat negara tersebut. $\mathrm{AKB}$ di Indonesia tertinggi terdapat di Sulawesi Barat (74/1000 KH) dan Nusa Tenggara Barat (72/1000 KH) angkanya mencapai hampir empat kali lipat dari provinsi dengan AKB terendah yaitu Yogyakarta (19/1000 KH).

Kabupaten Bima merupakan salah satu daerah otonom di Provinsi Nusa Tenggara Barat, terletak di ujung timur Pulau Sumbawa. Jumlah kematian bayi di Kabupaten Bima pada tahun 2007-2012 secara berurutan adalah 43; 38; 31; 29; 29; dan 94 bayi. $^{3}$ Adapun penyebabnya adalah non infeksi sebesar 58 $(61,7 \%)$ dan infeksi sebesar 36 (38,3\%). Secara garis besar dari sisi penyebabnya, kematian bayi dapat disebabkan oleh faktor endogen dan eksogen.

Tujuan penelitian ini adalah untuk mengetahui faktor risiko pendapatan keluarga, umur ibu, jarak kelahiran, frekuensi ANC, tempat persalinan, berat bayi lahir, ASI eksklusif, immunisasi, pengetahuan ibu tentang perawatan bayi, sumber air bersih dan frekuensi penyuluhan terhadap kematian bayi di Kabupaten Bima, Nusa Tenggara Barat.

\section{METODE}

Rancangan penelitian ini adalah studi kasus kontrol. Pengumpulan data dilaksanakan mulai dari Bulan Maret-April 2013. Populasi kasus adalah bayi yang meninggal selama periode Januari sampai Desember 2012 dan populasi kontrol adalah bayi yang masih hidup pada periode yang sama. Keseluruhan sampel berjumlah 153 bayi yang dihitung dengan menggunakan rumus sampel dengan multiple control, ${ }^{4}$ dimana 1 kasus berbanding 2 kontrol dengan asumsi OR (odds ratio) terkecil yang dianggap bermakna adalah 3 , tingkat kemaknaan $\alpha=0,05$, power $(1-\beta)=80 \%$ atau 0,80 dan proporsi sumber air bersih sebesar $60 \%$ didapatkan sampel sebanyak 51 kasus dan 102 kontrol. Pemilihan sampel kasus dan kontrol dilakukan secara stratified proportional sampling. Data dalam penelitian ini dikumpulkan dengan wawancara terhadap responden penelitian menggunakan kuesioner. Pengumpulan data dilakukan oleh peneliti sendiri dibantu oleh bidan desa.

Analisis data dilakukan secara bertahap meliputi analisis univariat, bivariat dan multivariat. Karakteristik responden dianalisis secara univariat dengan membandingkan antara kelompok kasus dan kontrol. Hubungan faktor risiko dengan kematian bayi dianalisis secara bivariat dan multivariat. Analisis bivariat menggunakan uji chi square dengan tingkat kemaknaan 0,05. Adanya hubungan faktor risiko dengan kematian bayi ditunjukkan dengan nilai $\mathrm{p}<0,05$; nilai OR $>1$ dan 95\%CI tidak mencakup nilai 1. Analisis multivariat menggunakan regresi logistik metode forward dengan tingkat kemaknaan 0,05. Penelitian ini mendapatkan kelaikan etik dari Komisi Etik Penelitian Fakultas Kedokteran Universitas Udayana dan Rumah Sakit Umum Pusat Sanglah Denpasar.

\section{HASIL}

Semua responden yang terpilih, baik pada kasus maupun kontrol dapat berpartisipasi dalam penelitian ini dan tidak ada penolakan. Pada Tabel 1 terlihat bahwa kelompok kasus tidak mirip dengan kelompok kontrol dalam hal umur, pendidikan suami, pekerjaan ibu, status ekonomi, kepemilikan kartu menuju sehat (KMS) dan jenis jamban $(\mathrm{p}<0,05)$. Sedangkan untuk variabel pekerjaan suami, tingkat pendidikan ibu, tempat melakukan pemeriksaan antenatal care (ANC) serta pemeriksa saat ANC pada kelompok kasus tidak berbeda apabila dibandingkan dengan kelompok kontrol.

Analisis bivariat pada Tabel 2 menunjukkan bahwa semua variabel meningkatkan risiko kematian bayi dengan OR tertinggi adalah frekuensi penyuluhan kesehatan $(\mathrm{OR}=7,95$; 95\%CI: 3,73-16,95), frekuensi penyuluhan kesehatan yang jarang meningkatkan risiko hampir 8 kali kematian bayi dibandingkan dengan frekuensi penyuluhan kesehatan yang sering, sedangkan terendah adalah umur ibu (OR=4,13; 95\%CI: 1,76-9,72), umur ibu $<20$ atau $>35$ tahun meningkatkan risiko 4,13 kali kematian bayi dibandingkan umur ibu 20-35 tahun.

Hasil analisis regresi logistik metode forward disajikan pada Tabel 3. Dari 11 faktor risiko yang dianalisisterdapatenamyangterbuktimeningkatkan risiko kejadian kematian bayi. Keenam variabel di atas memberikan pengaruh sebesar $61,1 \%$ terhadap kematian bayi di Kabupaten Bima. Faktor berat bayi lahir <2500 gr merupakan determinan kematian bayi utama dengan OR=7,38 (95\%CI: 2,04-26,70). Berat bayi lahir <2500 gr meningkatkan risiko 7,3 kali kematian bayi dibandingkan dengan berat bayi lahir $\geq 2500$ gr (95\%CI: 2,04-26,70) dan faktor risiko 
Tabel 1 Perbandingan karakteristik demografi, sosial ekonomi dan kesehatan kasus kontrol di Kabupaten Bima tahun 2012

\begin{tabular}{|c|c|c|c|}
\hline Karakteristik & $\begin{array}{l}\text { Kasus } \\
(n=51)\end{array}$ & $\begin{array}{l}\text { Kontrol } \\
(n=102)\end{array}$ & Nilai $p$ \\
\hline \multicolumn{4}{|l|}{ Umur ibu } \\
\hline$<20$ tahun & $10(19,6)$ & $0(0)$ & 0,000 \\
\hline$>35$ tahun & $7(13,7)$ & $11(10,8)$ & \\
\hline 20-35 tahun & $34(66,7)$ & $91(89,2)$ & \\
\hline \multicolumn{4}{|l|}{ Tingkat pendidikan ibu } \\
\hline Dasar & $26(51,0)$ & $35(34,3)$ & 0,046 \\
\hline Menengah & $22(43,1)$ & $56(54,9)$ & \\
\hline Tinggi & $3(05,9)$ & $11(10,8)$ & \\
\hline \multicolumn{4}{|l|}{ Tingkat pendidikan suami } \\
\hline Dasar & $28(54,9)$ & $20(19,5)$ & 0,000 \\
\hline Menengah & $20(39,2)$ & $67(65,7)$ & \\
\hline Tinggi & $3(05,9)$ & $15(14,7)$ & \\
\hline \multicolumn{4}{|l|}{ Jenis pekerjaan suami } \\
\hline Tidak terdidik & $8(15,7)$ & $13(12,7)$ & 0,266 \\
\hline Terlatih & $41(80,4)$ & $79(77,5)$ & \\
\hline Terdidik & $2(03,9)$ & $10(09,8)$ & \\
\hline \multicolumn{4}{|l|}{ Jenis pekerjaan ibu } \\
\hline Tidak bekerja & $47(92,2)$ & $58(56,9)$ & 0,000 \\
\hline Bekerja & $4(07,8)$ & $44(43,1)$ & \\
\hline \multicolumn{4}{|l|}{ Status ekonomi } \\
\hline Miskin & $31(62,0)$ & $25(24,5)$ & 0,000 \\
\hline Tidak miskin & $20(38,0)$ & $77(75,5)$ & \\
\hline \multicolumn{4}{|l|}{ Tempat ANC } \\
\hline $\begin{array}{l}\text { Bukan fasilitas } \\
\text { kesehatan }\end{array}$ & $3(5,9)$ & $2(2,0)$ & 0,200 \\
\hline Fasilitas kesehatan & $48(94,1)$ & $100(98,0)$ & \\
\hline \multicolumn{4}{|l|}{ Pemeriksa ANC } \\
\hline Bukan tenaga kesehatan & $4(7,8)$ & $2(2,0)$ & 0,078 \\
\hline Tenaga kesehatan & $47(92,2)$ & $100(98,0)$ & \\
\hline \multicolumn{4}{|l|}{ Kepemilikan KMS } \\
\hline Tidak memiliki & $22(43,1)$ & $4(3,9)$ & 0,000 \\
\hline Memiliki & $29(56,9)$ & $98(96,1)$ & \\
\hline \multicolumn{4}{|l|}{ Jenis jamban } \\
\hline Cemplung & $36(70,6)$ & $39(38,2)$ & 0,000 \\
\hline Septic tank & $15(29,4)$ & $63(61,8)$ & \\
\hline
\end{tabular}

paling rendah adalah sumber air dengan $\mathrm{OR}=3,72$ (95\%CI: 1,35-10,25).

\section{DISKUSI}

Hasil penelitian menunjukkan bahwa dari 11 faktor risiko yang dianalisis terdapat enam variabel yang dapat meningkatkan risiko kematian bayi di Kabupaten Bima, sedangkan lima faktor risiko lain tidak terbukti secara bermakna meningkatkan risiko kematian bayi yaitu: frekuensi ANC, tempat persalinan, berat bayi lahir, pengetahuan ibu tentang perawatan bayi dan kelengkapan immunisasi.

\section{Faktor ibu}

Kematian bayi yang terjadi di Kabupaten Bima kebanyakan terjadi pada ibu yang berumur $<20$ atau $>35$ tahun dengan risiko 6,6 kali dibandingkan 
Tabel 2 Crude OR faktor risiko kematian bayi di Kabupaten Bima tahun 2012

\begin{tabular}{|c|c|c|c|c|c|}
\hline Faktor Risiko & Kasus & Kontrol & OR & $95 \% \mathrm{Cl}$ & Nilai p \\
\hline \multicolumn{6}{|l|}{ Pendapatan keluarga } \\
\hline $\begin{array}{l}\text { Dibawah upah minimum regional } \\
\text { (UMR) }\end{array}$ & $46(90,2)$ & $68(66,7)$ & 4,60 & $1,67-12,63$ & 0,002 \\
\hline Diatas UMR & $5(9,8)$ & $34(33,3)$ & & & \\
\hline \multicolumn{6}{|l|}{ Jarak kelahiran } \\
\hline$<24$ bulan & $20(39,2)$ & $11(10,8)$ & 5,33 & $2,30-12,37$ & 0,000 \\
\hline$\geq 24$ bulan & $31(60,8)$ & $91(89,2)$ & & & \\
\hline \multicolumn{6}{|l|}{ Umur ibu } \\
\hline$<20$ atau $>35$ th & $17(33,3)$ & $11(10,8)$ & 4,13 & $1,76-9,72$ & 0,001 \\
\hline 20-35 tahun & $34(66,7)$ & $91(89,2)$ & & & \\
\hline \multicolumn{6}{|l|}{ Frekuensi ANC } \\
\hline$<4$ kali & $14(27,5)$ & $8(7,8)$ & 4,44 & $1,72-11,47$ & 0,001 \\
\hline$\geq 4$ kali & $37(72,5)$ & $94(92,2)$ & & & \\
\hline \multicolumn{6}{|l|}{ Pengetahuan ibu tentang perawatan bayi } \\
\hline Kurang & $31(60,8)$ & $19(18,6)$ & 6,77 & $3,19-14,35$ & 0,000 \\
\hline Baik & $20(39,2)$ & $83(81,4)$ & & & \\
\hline \multicolumn{6}{|l|}{ Berat bayi lahir } \\
\hline$<2500 \mathrm{gr}$ & $17(33,3)$ & $8(7,8)$ & 5,87 & $2,32-14,85$ & 0,000 \\
\hline$\geq 2500$ gr & $34(66,7)$ & $94(92,2)$ & & & \\
\hline \multicolumn{6}{|l|}{ Imunisasi } \\
\hline Tidak lengkap & $10(19,6)$ & $5(4,9)$ & 4,73 & $1,52-14,70$ & 0,004 \\
\hline Lengkap & $41(80,4)$ & $97(95,1)$ & & & \\
\hline \multicolumn{6}{|l|}{ Pemberian ASI ekslusif } \\
\hline Tidak eksklusif & $40(78,4)$ & $44(43,1)$ & 4,79 & $2,21-10,39$ & 0,000 \\
\hline Eksklusif & $11(21,6)$ & $58(56,9)$ & & & \\
\hline \multicolumn{6}{|l|}{ Tempat persalinan } \\
\hline Bukan fasilitas kesehatan & $5(9,8)$ & $2(2,0)$ & 5,43 & $1,01-29,06$ & 0,029 \\
\hline Fasilitas kesehatan & $46(90,2)$ & $100(98,0)$ & & & \\
\hline \multicolumn{6}{|l|}{ Frekuensi penyuluhan } \\
\hline Jarang & $35(68,6)$ & $22(21,6)$ & 7,95 & $3,73-16,95$ & 0,000 \\
\hline Sering & $16(31,4)$ & $80(78,4)$ & & & \\
\hline \multicolumn{6}{|l|}{ Sumber air bersih } \\
\hline Non pipa & $36(70,6)$ & $28(27,5)$ & 6,34 & $3,01-13,33$ & 0,000 \\
\hline Pipa & $15(29,4)$ & $74(72,5)$ & & & \\
\hline
\end{tabular}

Tabel 3 Adjusted OR faktor risiko kematian bayi di Kabupaten Bima tahun 2012

\begin{tabular}{lccc}
\hline Faktor Risiko & Adjusted OR & $\mathbf{9 5 \%} \mathbf{C l}$ & Nilai p \\
\hline Berat bayi lahir $<2500$ gr & 7,38 & $2,04-26,70$ & 0,002 \\
Jarak kelahiran $<24$ bulan & 6,69 & $2,11-21,16$ & 0,001 \\
Umur ibu $<20$ atau $>35$ tahun & 6,63 & $1,84-23,90$ & 0,004 \\
ASI tidak eksklusif & 6,23 & $2,10-18,46$ & 0,001 \\
Frekuensi penyuluhan jarang & 6,02 & $2,17-16,65$ & 0,001 \\
Sumber air bersih non perpipaan & 3,72 & $1,35-10,25$ & 0,011 \\
\hline
\end{tabular}

$\mathrm{R} 2=0,611$ 
dengan umur ibu 20-35 tahun. Menurut Saifuddin, ${ }^{5}$ umur ibu merupakan salah satu faktor yang dapat mempengaruhi tingkat kelangsungan hidup bayi, karena berisiko terhadap timbulnya masalah-masalah pada ibu dan bayinya. Menurut penelitian Suradi $\mathrm{dkk}^{6}$ usia ibu kurang dari 20 tahun mempunyai risiko 1,27 kali untuk melahirkan bayi dengan BBLR dibandingkan dengan usia ibu 20-35 tahun dan usia ibu lebih dari 35 tahun mempunyai risiko 2,10 kali untuk melahirkan bayi dengan BBLR dibandingkan dengan usia 20-35 tahun. Umur ibu $<20$ tahun dianggap berisiko karena organ reproduksi belum sempurna untuk menerima kehamilan, melahirkan serta merawat bayi. Sebaliknya umur yang terlalu tua $>35$ tahun mempunyai kecenderungan munculnya berbagai penyakit, sehingga dapat mengancam pertumbuhan dan dapat menimbulkan kematian bayi.

Pada penelitian ini, di Kabupaten Bima ditemukan umur ibu muda ( $<20$ tahun) pada kasus sebesar $19,6 \%$. Umur perkawinan pertama seorang ibu berhubungan dengan kematian bayi. Semakin muda seorang ibu memutuskan untuk melakukan pernikahan, semakin panjang masa reproduksi sehingga memungkinkan untuk melahirkan lebih dari satu anak. Menurut Wiknjosastro ${ }^{7}$ proporsi kematian terbanyak terjadi pada ibu dengan paritas $>3$ anak dan dengan jarak kelahiran kurang dari dua tahun. Penelitian Nazrul $\mathrm{dkk}^{8}$ di Bangladesh menunjukkan bahwa jarak kelahiran berpengaruh terhadap kematian bayi. Jika kelahiran sebelumnya dengan interval lebih panjang, maka risiko kematian lebih rendah.

Faktor lain yang dapat mempengaruhi kematian bayi adalah perawatan kehamilan dan pengetahuan ibu tentang perawatan bayi. Perawatan kehamilan merupakan suatu program yang berkesinambungan selama kehamilan, persalinan, kelahiran dan nifas yang terdiri atas edukasi, deteksi dini, pencegahan, pengobatan dan rehabilitasi yang bertujuan untuk memberikan rasa aman dan nyaman, sehingga ibu mampu merawat bayi dengan baik. ${ }^{9}$ Berdasarkan pedoman Kemenkes $\mathrm{RI}^{9}$ pelaksanaan ANC dilakukan minimal 4 kali, yaitu 1 kali pada trimester I, 1 kali pada trimester II dan 2 kali pada trimester III. Dari hasil penelitian menunjukkan bahwa frekuensi ANC tidak terbukti meningkatkan risiko kematian bayi, tetapi dalam analisis bivariat menunjukkan frekuensi ANC $<4$ kali meningkatkan risiko 4,44 kali terhadap kematian bayi dibanding dengan frekuensi ANC $\geq 4$ kali. Perbedaan ini menunjukkan bahwa frekuensi ANC berinteraksi dengan umur dan jarak kelahiran, dimana frekuensi ANC dalam analisis multivariat bukan satu-satunya variabel yang berhubungan dengan kematian bayi, sehingga hubungannya nampak menjadi lebih kecil bila ada variabel umur ibu dan jarak kelahiran.
Pengetahuan merupakan hasil tahu dari yang terjadi setelah orang melakukan pengindraan terhadap objek tertentu. ${ }^{10}$ Dalam penelitian ini menunjukkan bahwa pengetahuan ibu tentang perawatan bayi tidak terbukti meningkatkan risiko kematian bayi, tetapi dalam analisis bivariat menunjukkan pengetahuan ibu yang kurang tentang perawatan bayi meningkatkan risiko sebesar 6,77 kali kematian bayidibandingkan dengan pengetahuanibu yang baik. Perbedaan ini disebabkan karena adanya interaksi antara pengetahuan ibu tentang perawatan bayi dengan ASI. Penelitian ini mirip dengan hasil penelitian Atiek ${ }^{11}$ di Puskesmas Mojolaban I Kabupaten Sukoharjo yang menunjukkan bahwa tidak ada hubungan yang bermakna antara tingkat pengetahuan ibu dengan praktek cara perawatan balita yang menderita ISPA non pneumonia. Hal ini berarti tingkat pengetahuan yang tinggi belum tentu memiliki praktek cara perawatan bayi dan balita baik.

\section{Faktor bayi}

Kelangsungan hidup bayi yang dilahirkan dalam periode neonatal dini sangat erat hubungannnya dengan berat badan lahir. Hasil penelitian menunjukkan bahwa berat bayi lahir <2500 gr meningkatkan risiko 7,3 kali kematian bayi dibandingkan dengan berat bayi lahir $\geq 2500$ gr. Penelitian oleh Wabena ${ }^{12}$ di Afrika menunjukkan bahwa berat bayi kurang dari 2500 gram berhubungan dengan meningkatnya kematian akibat infeksi saluran pernafasan dan hubungan ini menetap setelah dilakukan adjustment terhadap status pekerjaan orang tua, pendapatan dan pendidikan. Bayi dengan berat badan lahir rendah berisiko meningkatkan kematian karena bayi tersebut sangat rentan terhadap gangguan termoregulasi, kematangan organ paru-paru yang belum sempurna dan gangguan sistem peredaran darah.

Kematian bayi selain dipengaruhi oleh faktor berat badan lahir, dapat juga dipengaruhi oleh pemberian ASI eksklusif dan imunisasi. Hasil penelitian ini menunjukkan bahwa ASI tidak eksklusif meningkatkan risiko kematian bayi 6,23 kali dibandingkan dengan ASI eksklusif. Menurut Roesli ${ }^{13}$ ASI mengandung zat kekebalan tubuh yang mampu melindungi bayi dari berbagai penyakit infeksi bakteri, virus, dan jamur. Penelitian ini juga sesuai dengan penelitian Victoria $\mathrm{dkk}^{14}$ bahwa bayi pada usia dua bulan pertama yang tidak mendapat ASI mempunyai risiko kematian karena penyakit infeksi 6 kali lebih besar dari bayi yang mendapat ASI. Penelitian ini juga sesuai dengan penelitian Aggett ${ }^{15}$ bahwa ASI dapat meningkatkan kekebalan yang baru lahir karena mengandung zat kekebalan tubuh yang dapat melindungi bayi dari berbagai penyakit infeksi dan alergi. 
Pada penelitian ini salah satu faktor pemberian ASI yang tidak eksklusif adalah makanan pendamping air susu ibu (MPASI) dini. Menurut Adish ${ }^{16}$ bayi yang diberikan makanan pendamping ASI setelah berumur 6 bulan umumnya lebih cerdas dan memiliki daya tahan tubuh lebih kuat. Sedangkan jika makanan pendamping ASI diberikan terlalu dini justru dapat meningkatkan angka kematian bayi karena mengganggu sistem pencernaan bayi dan apabila terlambat memberikan MPASI juga akan membuat bayi kekurangan gizi. Penelitian ini sesuai dengan kondisi pemberian ASI di Kabupaten Bima, dimana masih banyak ibu menyusui sebelum ASI-nya keluar (pralaktal) pada hari pertama atau hari ketiga memberikan madu atau air putih bahkan susu formula kepada bayinya. Anjuran pemberian ini umumnya dilakukan atas saran dari nenek subyek yang berasumsi bahwa bayi menangis karena lapar oleh karena itu harus diberi minum atau makan. Selain itu di beberapa kecamatan, bagi ibu yang bekerja membantu suaminya di lahan pertanian atau peternakan, mereka hanya memberikan ASI pada pagi dan sore hari, sehingga waktu siang hari bayi biasanya diberi susu formula atau air tajin bahkan pada usia bayi 7 hari sudah diberi pisang atau nasi yang diulek dengan sendok.

Kelengkapan imunisasi berkaitan dengan angka kejadian penyakit infeksi. Imunisasi bertujuan untuk memberikan kekebalan terhadap antigen tertentu untuk mencegah penyakit dan kematian bayi atau anak. ${ }^{17}$ Dalam penelitian ini menunjukkan bahwa kelengkapan imunisasi tidak terbukti meningkatkan risiko terhadap kematian bayi, tetapi dalam analisis bivariat menunjukkan imunisasi yang tidak lengkap meningkatkan risiko 4,7 kali kematian bayi dibandingkan dengan imunisasi yang lengkap. Dapat dijelaskan juga bahwa dari 51 penyebab kematian bayi di Kabupaten Bima yang terdiri dari non infeksi sebesar $29(56,08 \%)$ yakni sindroma gawat nafas, asfixia berat, cacat bawaan, kelainan jantung dan hydrocephalus. Sisanya adalah infeksi sebesar 22 $(43,92 \%)$ yaitu: ISPA, diare, meningitis dan kejang demam. Jika dilihat dari penyebab tersebut, tidak satupun menunjukkan penyakit infeksi yang dapat dicegah dengan imunisasi dasar seperti hepatitis, poliomielitis, diphteri, pertusis serta tuberkulosis.

\section{Faktor pelayanan kesehatan}

Pelayanan kesehatan dalam penelitian ini mencakup penyuluhan kesehatan dan tempat melakukan persalinan. Frekuensi mengikuti penyuluhan kesehatan yang jarang meningkatkan risiko 6 kali terhadap kematian bayi. Menurut Azwar, ${ }^{18}$ penyuluhan kesehatan diartikan sebagai kegiatan pendidikan kesehatan yang dilakukan dengan cara menyebarluaskan pesan dan menanamkan keyakinan, dengan demikian masyarakat tidak hanya sadar, tahu dan mengerti, tetapi juga mau dan dapat melakukan anjuran yang berhubungan dengan kesehatan. Masalah kematian maupun kesakitan pada bayi dan anak sesungguhnya tidak terlepas dari faktor-faktor sosial budaya dan lingkungan di dalam masyarakat dimana mereka berada. Di Kabupaten Bima umumnya ibu akan hadir berbondongbondong mengikuti kegiatan penyuluhan kesehatan apabila ada sesuatu yang diberikan oleh petugas kesehatan misalnya pemberian makanan tambahan pada bayi atau ibu hamil. Jarang sekali mereka hadir karena kesadarannya sendiri berdasarkan kebutuhan atas kesehatannya.

Menurut Riskesdas ${ }^{19}$ tempat persalinan sangat erat hubungannya dengan kematian bayi. Semakin tinggi proporsi ibu yang melahirkan di tempat persalinan non-fasilitas kesehatan, semakin tinggi kematian ibu dan bayi. Dalam penelitian ini, tempat persalinan tidak terbukti meningkatkan risiko kematian bayi. Hal ini disebabkan kematian bayi ditempat persalinan non fasilitas kesehatan lebih sedikit, dibandingkan dengan tempat persalinan di fasilitas kesehatan baik pada kelompok kasus (90,2\%) maupun pada kelompok kontrol $(98,0 \%)$. Hal ini bukan berarti tempat persalinan tidak terbukti sebagai faktor risiko kematian bayi, tetapi cakupan persalinan di tempat fasilitas kesehatan sudah tercapai yaitu diatas $80 \%$.

\section{Faktor lingkungan}

Sumber air bersih non perpipaan meningkatkan risiko 3,7 kali kematian bayi dibandingkan dengan sumber air bersih perpipaan. Menurut $\mathrm{WHO},{ }^{20}$ kurangnya akses masyarakat terhadap air bersih dan sanitasi berkontribusi terhadap kematian 1,8 juta orang per tahun karena diare, terutama pada anak usia di bawah lima tahun. Hasil penelitian ini juga sesuai dengan penelitian Gloria ${ }^{21}$ yang menunjukkan bahwa risiko kematian anak empat kali lebih besar pada rumah tangga dengan sarana air bersih yang buruk dibandingkan dengan rumah tangga dengan sarana air bersih yang baik. Air merupakan kebutuhan pokok untuk kehidupan manusia. Penyediaan air bersih amat penting dalam pencegahan penyakit, fasilitas kebutuhan rumah tangga dan higiene makanan.

\section{Faktor pendapatan keluarga}

Menurut Friedman ${ }^{22}$ pendapatan keluarga diukur dengan banyaknya akumulasi pendapatan semua anggota keluarga, setelah dikonversi menjadi per bulan dan dibagi menjadi kelompok pendapatan rendah dan pendapatan tinggi.

Hasil penelitian ini menunjukkan bahwa pendapatan keluarga ternyata tidak terbukti meningkatkan risiko kematian bayi. Pada analisis bivariat, pendapatan keluarga yang rendah 
ditemukan dapat meningkatkan risiko kematian bayi 4,6 kali dibandingkan dengan pendapatan keluarga yang tinggi. Perbedaan hasil analisis ini kemungkinan disebabkan karena pendapatan keluarga berinteraksi dengan frekuensi penyuluhan kesehatan dan sumber air bersih dalam keluarga. Hal ini juga bertentangan dengan Teori Mosley ${ }^{23}$ berkaitan dengan kematian bayi, dimana disebutkan bahwa faktor sosial ekonomi merupakan determinan utama yang mempengaruhi kematian bayi.

Perbedaan ini dapat dijelaskan bahwa pada umumnya kehidupan masyarakat Kabupaten Bima tergolong daerah pedesaan dengan ragam kebutuhan yang relatif sederhana. Untuk kebutuhan hidup sehari-hari yang penting adalah cukup makan yang bersumber dari lahan pertanian, peternakan dan perikanan laut yang sudah tersedia. Masih kuatnya budaya gotong royong dalam struktur masyarakat Bima, dimana masyarakat pedesaan umumnya mempunyai hubungan kekeluargaan yang tinggi dalam membantu anggota keluarga lain yang mengalami kekurangan. Berbeda dengan masyarakat di perkotaan yang cenderung lebih individual.

\section{SIMPULAN}

Faktor yang terbukti meningkatkan risiko kematian bayi di Kabupaten Bima adalah: berat bayi lahir $<2500$ gr, jarak kelahiran <24 bulan, umur ibu $<20$ atau $>35$ tahun, pemberian ASI yang tidak eksklusif, frekuensi penyuluhan kesehatan yang jarang dan sumber air bersih non perpipaan dengan kontribusi sebesar 61,1\%. Beberapa upaya perbaikan dalam rangka penurunan angka kematian bayi di Kabupaten Bima antara lain meningkatkan pengawasan dan monitoring kepada puskesmas-puskesmas dalam kegiatan penyuluhan dan promosi tentang pentingnya nutrisi pada ibu hamil, pemberian ASI eksklusif sampai bayi berusia 6 bulan, penundaan usia perkawinan dan penjarangan kehamilan dengan berbagai inovasi dan metode yang sesuai dengan sasaran.

\section{UCAPAN TERIMA KASIH}

Ucapan terima kasih penulis sampaikan kepada masyarakat dan ibu-ibu di Kabupaten Bima, Kepala Dinas Kesehatan Kabupaten Bima, Kepala Badan Kesatuan Bangsa Politik dan Perlindungan Masyarakat Kabupaten Bima yang memberikan ijin penelitian, serta semua rekan yang telah membantu terselesainya penelitian ini.

\section{DAFTAR PUSTAKA}

1. Qumarul Hasan, Chowdhuryl. Socio-economic determinants of neonatal, postneonatal, infant and child mortality. International Journal of Sociology and Anthropology University of Rajshahi Bangladesh 2010 June; 2(6): pp. 118-125.
2. Bappenas. Kajian evaluasi pembangunan sektoral faktorfaktor yang mempengaruhi kelangsungan hidup anak. Jakarta; 2009.

3. Dinas Kesehatan Kab. Bima. Laporan Tahunan Dinas Kesehatan Kabupaten. Bima; 2012.

4. Schlesselman J. Case-control studies design conduct analysis. New York: Oxford University Press; 1928.

5. Saifuddin. Ilmu Kebidanan. Jakarta: Penerbit Yayasan Bina Pustaka Sarwono Prawirohardjo; 2008.

6. Suradi R, Monintja HE, Amalia P, Kusumowardhani D. Penanganan mutakhir bayi premature. Naskah lengkap pendidikan kedokteran berkelanjutan Bagian Ilmu Kesehatan Anak. Jakarta: Penerbit FKUI; 2003.

7. Wiknjosastro H. Ilmu Kebidanan Edisi Ketiga Cetakan Ketujuh. Jakarta: Yayasan Bina Pustaka Sarwono Prawirohardjo; 2002.

8. Nazrul Islam MD, Mondal MD. Factors influencing infant and child mortality-a case study of Rajshahi District Bangladesh. J Hum Ecol 2009; 26(1): 31-39.

9. Depkes. Pedoman pemantauan wilayah setempat kesehatan ibu dan anak (PWS-KIA). Jakarta: Direktorat Jenderal Pembinaan Kesehatan Masyarakat; 2004.

10. Notoatmojo. Pendidikan dalam perilaku kesehatan. Penerbit, Rineka Cipta; Jakarta; 2003.

11. Murharyati A. Hubungan antara tingkat pengetahuan dan sikap ibu dengan praktik cara perawatan balita yang menderita ISPA non-pneumonia di wilayah kerja Puskesmas Mojolaban I Kabupaten Sukoharjo. 2010. Jurnal Kesehatan Kusuma Husada; 1(1): 34-39.

12. Wabena A. Socio-economic factors affecting under five mortality in South Africa - An investigative study. Kyei Journal of Emerging Trends in Economics and Management Sciences 2011; 2 (2): 104

13. Roesli U. Inisiasi menyusui dini. Jakarta: Pustaka Bunda; 2008.

14. Victoria CG, Barross AJD. Effect of breastfeeding on infant and child mortality due to infectious diseases in less developed countries a pooled analysis. Lancet 2000: 355 (Akses: 25 Februari 2013).

15. Aggett PJ. Research priorities in complementary feeding. International Paediatric Assoaciation (IPA) and European Society of Paediatric Gastroenterology, Hepatology and Nutrition Workshop Paediatrics 2000: p.120 (Akses: 22 Februari 2013).

16. Adish A. Infant feeding breast and complementary feeding in Indonesia. A paper presented in 3 day course of management of child feeding practice. Jakarta; 2004.

17. Ranuh. Imunisasi dasar pada balita. Yogyakarta: Nuha Medika, 2008.

18. Azwar A. Pengantar ilmu kesehatan lingkungan cetakan ke-11. Jakarta: Mutiara Sumber Widya; 2009.

19. Riskesdas. Laporan RISKESDAS 2010, Provinsi Nusa Tenggara Barat. Departemen Kesehatan Republik Indonesia, Badan Penelitian dan Pengembangan Kesehatan; 2010

20. Dahlgren and Whitehead's. Social determinants of health. WHO CSDH; 2007.

21. Gloria Macassa L. Inequalities in child mortality in subSaharan Africa-A social epidemiologic framework. African Journal of Health Sciences 2011 June; 18(1-2): p.121-124.

22. Friedman. Keperawatan Keluarga. Jakarta: EGC; 1994.

23. Mosley W, Henry and Chen, Lincoln C. An analytical framework for WHO-Healthy environment for children alliance framework for action in the community. Technical Note No. 9 Draft Reviced 7.1.05 1, http;//www.who.org/ hdr; 2006. (Akses: 09 November, 2012).

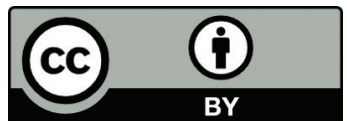

This work is licensed under a Creative Commons Attribution 